\title{
Effects of Grape seed Extract and Origanum Onites Essential Oil on Cisplatin-Induced Hepatotoxicity in Rats
}

\author{
Aysun CETIN ${ }^{1}$, Umit ARSLANBAS ${ }^{1}$, Berkay SARAYMEN ${ }^{2}$, Ozlem CANOZ ${ }^{3}$, \\ Ahmet OZTURK $^{4}$, Osman SAGDIC ${ }^{5}$ \\ ${ }^{1}$ Erciyes University, Faculty of Medicine, Department of Biochemistry and Clinical Biochemistry \\ ${ }^{2}$ Erciyes University, Faculty of Pharmacy, Department of Biochemistry \\ ${ }^{3}$ Erciyes University, Faculty of Medicine, Department of Pathology \\ ${ }^{4}$ Erciyes University, Faculty of Medicine, Department of Bioistatistics \\ ${ }^{5}$ Erciyes University, Faculty of Engineering, Department of Food Engineering, Kayseri, TURKEY
}

\begin{abstract}
Cisplatin is a widely used anticancer drug but, it can produce undesirable effects such as hepatotoxicity even in therapeutic doses. The underlying mechanism in hepatotoxicity has been attributed to free oxygen radicals. The present study was designed to determine the possible protective effects of grape seed extract (GSE) and Origanum onites essential oil (OOEO) on liver toxicity induced by cisplatin. Ninetysix-male Wistar albino rats were divided into eight groups, twelve in each (Control, GSE, OOEO, GSE+OOEO, Cisplatin, GSE+ Cisplatin, OOEO+ Cisplatin, GSE+OOEO+ Cisplatin) and followed up for 10 days. Cisplatin and OOEO were injected intraperitoneally. GSE was administered with gavage. The histopathological examination of liver tissues was performed by light microscope. Superoxide dismutase (SOD), glutathione peroxidase (GSH-Px) activities and malondialdehyde (MDA) levels were determined in liver tissues. Alanine aminotransferase (ALT) and aspartate aminotransferase (AST) levels were measured in serum. Cisplatin-induced considerable hepatocyte damage under microscopic examination, and an increase in MDA levels as well as a decrease in the activities of antioxidant enzymes, including SOD, GSH-Px in liver tissues and an increase in serum ALT and AST $(p<0.001)$. The addition of GSE and/or OOEO significantly prevented microscopic tissue damage, reversed oxidative stress parameters and biochemical values compared to the cisplatin group $(p<0.001)$. In conclusion GSE and OOEO may be used in adjuvant therapy to prevent cisplatin-induced hepatotoxicity, but further studies using various doses, different time intervals, and a larger number of animals need to be carried out.
\end{abstract}

Keywords: Cisplatin, Hepatotoxicity, Free Radicals, Grape, Thyme

\section{ÖZET}

Sisplatin, kanser tedavisinde yaygın olarak kullanılan fakat tedavi dozlarında dahi karaciğer hasarı gibi istenmeyen yan etkilere sebep olabilen bir ilaçtır. Sisplatinin karaciğer dokusunda yaptığı hasarın altında yatan mekanizma büyük oranda serbest oksijen radikallerine bağıdır. Bu çalışmada sıçanlarda sisplatin tedavisine bağı oluşan karaciğer hasarında üzüm çekirdeği özütünün (ÜçÖ) ve esansiyel kekik yağının (EKY) muhtemel koruyucu etkilerinin araştırıması amaçlanmıştır. Doksanaltı adet Wistar albino cinsi erkek sıçan; her biri oniki hayvandan oluşan sekiz gruba bölünerek (Kontrol, ÜçÖ, EKY, ÜÇÖ+EKY, Sisplatin, ÜÇÖ+Sisplatin, EKY+Sisplatin, ÜçÖ+EKY+Sisplatin), on gün süreyle takip edildi. 
Sisplatin ve EKY periton içine enjekte edilirken, ÜçÖ gavaj yoluyla verildi. Karaciğer dokuları histopatolojik incelemesi ışık mikroskobunda yapıldı. Karaciğer doku örneklerinde süperoksit dismutaz (SOD), glutatyon peroksidaz (GSH-Px) aktiviteleri ve malondialdehit (MDA) düzeyleri çalışıldı. Serum alanin aminotransferaz (ALT) ve aspartat aminotransferaz (AST) düzeyleri ölçüldü. Sisplatin ışık mikroskobu altında belirgin karaciğer hasarı, serum ALT ve AST düzeylerinde artış, MDA düzeylerinde yükselme ve SOD ile GSH-Px'i içeren antioksidan enzim aktivitelerinde e azalmaya yol açtı ( $p<0.001)$. ÜçÖ ve/veya EKY eklenmesi mikroskobik doku hasarını engelledi, oksidatif parametreleri ve biyokimyasal değerleri cisplatin grubuna göre belirgin düzeltti $(p<0.001)$. Sonuç olarak sisplatinin yol açtığı hasarı önlemede ÜçÖ ve EKY' nın adjuvan tedavide kullanılabileceği fakat farklı doz, farkı süre ve daha fazla denek sayılarılla yeni çalışmaların yapıımasının uygun olacağı kanısına varıldı.

Anahtar Kelimeler: Sisplatin, Hepatotoksisite, Serbest Radikaller, Üzüm, Kekik

\section{INTRODUCTION}

Cisplatin (cis-diamminedichloroplatinum II) is one of the most widely used antineoplastic agents in the treatment of solid tumour and haematological malignancies. ${ }^{1}$ Despite its significant antitumour activity, the clinical use of cisplatin is often limited by its undesirable side-effects e.g. nephrotoxicity and neurotoxicity, which are examples of the most severe and dose limiting effects. ${ }^{2.3}$ Nevertheless, other less frequent toxic effects, such as hepatoxicity, which is frequently seen after the administration of high doses of cisplatin, can alter the clinical situation of patients. ${ }^{4-6}$ Although cisplatin-induced nephrotoxicity has been very well documented in clinical oncology, hepatotoxicity has been rarely characterized and less studied. El-Sayyad et al. showed that cisplatin induced drastic abnormalities in liver tissue histology and the ultrastructure with respect to direct toxic effect on hepatocyte organels. ${ }^{7}$ Like other chemotherapeutics, cisplatin causes excessive reactive oxygen species (ROS) generation and also induces a decrease in plasma antioxidant levels, which may reflect a failure of the antioxidant defence mechanism against oxidative damage..$^{8-10}$

Superoxide dismutase (SOD) and glutathione peroxidase (GSH-Px) are endogenous antioxidants and their natural supplements play a role in the prevention of cisplatin-induced oxidative injury in cancer patients. ${ }^{11}$ When an atioxidants are administered as an adjuvant therapy in rats receiving cisplatin, a significant clinical improvement is obtained. It has been demonstrated that a high dose of vitamin $\mathrm{E}$, or a combination of antioxidants, restored GSH-Px activity with a concomitant reduction in malondialdehyde (MDA) levels for prevention of cisplatin side effects..$^{12}$ In another study, cisplatin induced mitochondrial sensitivity prevented by the thiol group of protective antioxidant agents, namely glutathi- one, dithiothreitol, N-acetyl-L-cysteine and cysteine, whereas SOD, catalase and ascorbate. ${ }^{13}$

Grape seed extract (GSE) contains a number of polyphenols, including procyanidins and proanthocyanidins, which are powerful free radical scavengers. Grape seed proanthocyanidin extract is a rich source of polyphenolic antioxidants, a naturally occurring family of oligomeric proanthocyanidins found in a wide range of fruit and vegetables. ${ }^{14,15}$ A number of studies have demonstrated the superior free radical scavenging ability of GSE as compared to vitamins $\mathrm{C}, \mathrm{E}$ and $\beta$-carotene. ${ }^{14,16}$

Turkish oregano (Origanum onites L.), a member of the mint family, Lamiaceae, is well known for its antioxidative activity. Carvacrol and thymol, the two main phenols that constitute about $78-82 \%$ of the essential oil of oregano, are principally responsible for its activity. ${ }^{17}$ Origanum also contains phenolic terpenoids, flavonoids, tannins, phenolic glycosides and sitosterol. Authors have reported a broad spectrum of pharmacological and therapeutic effects provided by origanum including antioxidant, antispasmodic, antitumoural, antimicrobial, antifungal, diuretic and analgesic activities..$^{18,19}$

The aim of this study was to investigate the role of oxidative stress on cisplatin-induced hepatotoxicity and the possible protective roles of antioxidant food supplementation on this toxicity through tissue oxidant/antioxidant parameters and light microscopic evaluation.

\section{MATERIALS and METHODS}

Animals: Ninety-six adult male Wistar albino rats, initially weighing 230-310 g at 16 weeks old, were purchased from The Animal Laboratory of the Faculty of Medicine at Erciyes University. The animals were fed with a commercial standard diet and 
water ad libitum during the experimental period, and were kept at an ambient room temperature of $20-22^{\circ} \mathrm{C}$, with a relative humidity of $50 \pm 5 \% ; 12: 12$ $\mathrm{h}$ light and dark cycles were maintained. All animals were housed for acclimatization for 1 week before the experiments. This research was performed in accordance with the National Guide for the Care and Use of Laboratory Animals and approved by the Local Ethics Committee at the University.

Experimental design: The animals were randomly divided into eight groups (Control, GSE, OOEO, GSE+OOEO, Cisplatin, GSE+Cisplatin, OO$\mathrm{EO}+$ Cisplatin, GSE+OOEO+ Cisplatin), each group consisting of 12 rats. As a preventive supplement GSE (100 mg/ kg-bw solution was administered with gavage by a curved 3-inch long 16-gauge gavage tube inserted after applying a proper restraint) and OOEO (1 mg/ kg-bw, intraperitoneally), and as a placebo distilled water (orally with gavage) were given to each group throughout the 10 days. The GSE+OOEO group was administered with two preventive supplements in the same dose and in a similiar manner. As a therapeutic implement physiological saline was given to the control, GSE, OEOE and GSE+OOEO groups (ip, as a placebo) and cisplatin $(7 \mathrm{mg} / \mathrm{kg}$, single dose, intraperitoneally) was given to the cisplatin, GSE+cisplatin, OOEO+cisplatin and GSE+OOEO+cisplatin groups on the 6th day. On the 11th day liver tissue and serum samples were obtained from the rats under deep anaesthesia. The liver samples were then removed from the animals and immediately stored at $-30^{\circ} \mathrm{C}$ until analysis.

Preparation of Grape Seed Extract: Ripened grapes (Vitis vinifera $\mathrm{L}$ ) from the most popular wine making grape cultivars grown in Turkey, Okuzgozu (red grape cultivar), were obtained from the Tokat region of Turkey. The grape seed powder $(100 \mathrm{~g})$ was extracted in a Soxhlet extractor with petroleum ether $\left(60^{\circ} \mathrm{C}\right.$ for 6 hours $)$ to remove the fatty materials. The defatted grape seed powder was re-extracted in a Soxhlet apparatus for 8 hours with $200 \mathrm{ml}$ ethanol. The extract was then concentrated in a rotary evaporator (Rotavator Evaporator R 200, Buchi, Switzerland) under vacuum at $<40^{\circ} \mathrm{C}$ to lyophilize the crude extracts (Labconco Freezone 2.5, Missouri, US), It was then stored in a dark bottle at $4^{\circ} \mathrm{C}$ until use. The concentration of total phenolic compounds in the seed extract was determined by the Folin-Ciocalteu colourimetric method. The Total phenolics were expressed as gallic acid equivalents (milligram GAE per gram extract).$^{20}$ The content of total phenolics was found as $587.4 \pm 5.6 \mathrm{mg}$ $\mathrm{GAE} / \mathrm{g}$ in the grape seed extracts.

Preparation of wild oregano essential oils: Origanum onites samples were collected from Izmir (Turkey). The wild oregano (Origanum onites) essential oils were produced by the Clevenger hydrodistillation method. Plant materials (500 g), cut into small pieces, were placed in a distillation apparatus with double distilled water and hydrodistilled for $3 \mathrm{~h}$. The essential oil was dried over anhydrous sodium sulfate, filtered and stored at $-60^{\circ} \mathrm{C}$ until analysis. ${ }^{21}$ The chemical compositions of the wild oregano essential oils were found as $0.92 \%$ myrcene, $0.73 \% \alpha$-terpinene, $3.02 \% \alpha$-terpinene, $2.91 \%$ p-cymene, $5.18 \%$ linalool, $6.21 \%$ thymol and $80.23 \%$ carvacrol.

Chemicals: All chemicals were obtained from Sigma Chemical Inc. (St. Louis, MO, USA) and all organic solvents from Merck Chemical Inc. (Darmstadt, Germany) except for cisplatin. Cisplatin (Cisplatinum Ebewe $1 \mathrm{mg} \mathrm{ml}^{-1}$ ) was obtained from the Liba Drug Company, Istanbul, Turkey. All reagents were analytical grade. All reagents except for the phosphate buffers were prepared each day and stored in a refrigerator at $+4^{\circ} \mathrm{C}$. The reagents were equilibrated at room temperature for $0.5 \mathrm{~h}$ before use, either at the start of analysis or when reagent containers were refilled. Phosphate buffers were stable at $+4^{\circ} \mathrm{C}$ for 1 month.

Biochemical determinations: The livers were excised immediately and homogenized in a 10 -fold volume of phosphate buffer solution at $\mathrm{pH} \mathrm{7.4,}$ using a homogenizer (Ultra-Turrax $\mathrm{T}$ 25, IKA; Werke 24.000 r.p.m, Germany). All preparation procedures were performed at $+4^{\circ} \mathrm{C}$. The homogenates were centrifuged at $10.000 \mathrm{x}$ g for about 60 min and the resulting supernatants were stored at $80^{\circ} \mathrm{C}$ until for MDA, SOD and GSH-Px assays.

Determination of MDA Level: The levels of MDA in liver tissue were assessed according to the method of Ohkawa et al. ${ }^{22}$ The assay procedure to determine the MDA levels in the rat livers was set up as follows: to samples less than $0.2 \mathrm{ml}$ of $10 \%$ $(\mathrm{w} / \mathrm{v})$ tissue homogenate, $0.2 \mathrm{ml}$ of $8.1 \%$ sodium dodecyl sulphate and $1.5 \mathrm{ml}$ of $20 \%$ acetic acid so- 
lution were added. The $\mathrm{pH}$ was adjusted to 3.5 with $\mathrm{NaOH}$ and $1.5 \mathrm{ml}$ of $0.8 \%$ aqueous TBA solution. The final volume was brought to $4 \mathrm{ml}$ by distilled water and then heated in an water bath at $95^{\circ} \mathrm{C}$ for 60 min using a glass ball as a condenser. After cooling with tap water, $1.0 \mathrm{ml}$ of distilled water and $5.0 \mathrm{ml}$ of an $\mathrm{n}$-butanol and pyridine $(15: 1 \mathrm{v} / \mathrm{v}) \mathrm{mix}-$ ture were added and the mixture was shaken vigorously. After centrifugation at $4.000 \mathrm{rpm}$ for 10 min, the organic layer was removed and its absorbance was measured at $532 \mathrm{~nm}$. Tissue MDA levels were expressed in nanomoles MDA per milligram of protein in tissue homogenates ( $\mathrm{nmol} / \mathrm{mg}$ protein). Protein concentrations were measured by the Lowry method..$^{23}$

Determination of SOD Activity: Total $(\mathrm{Cu}-\mathrm{Zn}$ and Mn) SOD (EC 1.15.1.1) activity was determined according to the method of Sun et al. ${ }^{24}$ The principle of this method is based on the inhibition of NBT reduction by the xanthine-xanthine oxidase system as a superoxide generator. Activity was assessed in the ethanol phase of the supernatant after a $1.0 \mathrm{ml}$ ethanol/chloroform mixture $(5 / 3, \mathrm{v} / \mathrm{v})$ was added to the same volume of sample and centrifuged at 4000 g. One unit of SOD was defined as the amount of enzyme causing $50 \%$ inhibition in the NBT reduction rate. SOD activity was also expressed as units per milligram liver protein.

Determination of GSH-Px Activity: GSH-Px (EC 1.6.4.2) activity was measured by the method of Paglia et al. ${ }^{25}$ The enzyme reaction in a tube containing NADPH, reduced glutathione (GSH), sodium azide, and GSH reductase was initiated by the addition of $\mathrm{H}_{2} \mathrm{O}_{2}$ and the change in absorbance at 340 nm was monitored with a spectrophotometer. Activity was given as units per gram protein in liver tissue and all samples were assayed in duplicate.

Determination of Liver Functions: Serum ALT and AST levels were measured to evaluate liver function by using reagents (Thermo Electron $\mathrm{CO}$, USA) for Olympus Analysers. All liver enzyme assays were performed spectrophotometrically using an Olympus AU 2700 autoanalyser (Olympus CO, Tokyo, Japan). ALT, AST levels were also expressed as units per litre.

Histopathological Examinations: For the histopathological examinations, the liver tissue samples taken from the rats were fixed in $10 \%$ phosphate buffered formalin and embedded in paraffin. Then, $5 \mu \mathrm{m}$ sections were cut from the parafin blocks and stained with hematoxylen-eosin. Liver sections were blindly observed under a light microscope and scored to assess histopathological changes according to the following grading system: 0 , normal; 1 , mild hydropic degeneration, no Kupffer cell proliferation and no necrosis; 2, moderate hydropic degeneration, Kupffer cell proliferation and no or little necrosis; 3, severe hydropic degeneration, Kupffer cell proliferation and necrosis. ${ }^{26}$

Statistical Analysis: Data were expressed as mean \pm standard deviation $\left(\chi_{ \pm} \mathrm{SD}\right)$ (for normally distributed data), or as median with $25 \%-75 \%$ percentile (for skewed data). Comparisons of MDA, SOD, GSH-Px, AST and ALT between the groups were made by using a One Way Analysis of Variance (ANOVA). Post-hoc comparisons on parameters were performed using the Tukey procedure. Comparisons of groups for histopathological examinations were made by using a Kruskal-Wallis analysis of variance (Post-hoc comparisons: Dunn's test). All analyses were performed with the statistical package for scientists (SIGMASTAT) Windows version 3.5 and p values less than 0.05 were regarded as statistically significant.

\section{RESULTS}

Cellular damage was observed in liver the samples of cisplatin-injected animals. The liver morphology was characterized by severe activation of Kupffer cells, degenerated hepatocytes and moderate enlargement of the sinusoids (Figure 1). The microscopic damage score of the liver samples was significantly higher in the cisplatin-injected group (median score: 2, range 1.75-2.25) than those of the other groups ( $\mathrm{p}<0.05)$; Cisplatin: 2 (range 1.75 2.25). The addition of GSE and OOEO effectively improved microscopic appearance and also significantly reduced the histopathological scores (median scores: GSE+Cisplatin: 1, range 1-2; OOEO+Cisplatin: 1, range 1-2; GSE + OOEO + Cisplatin: 1, range 1-1.5) as compared to cisplatintreated groups $(\mathrm{p}<0.05)$.

The biochemical oxidation parameter results are expressed in Figure 2. All groups were compared with each other statistically. GSE and GSE+OOEO administration significantly decreased MDA levels 

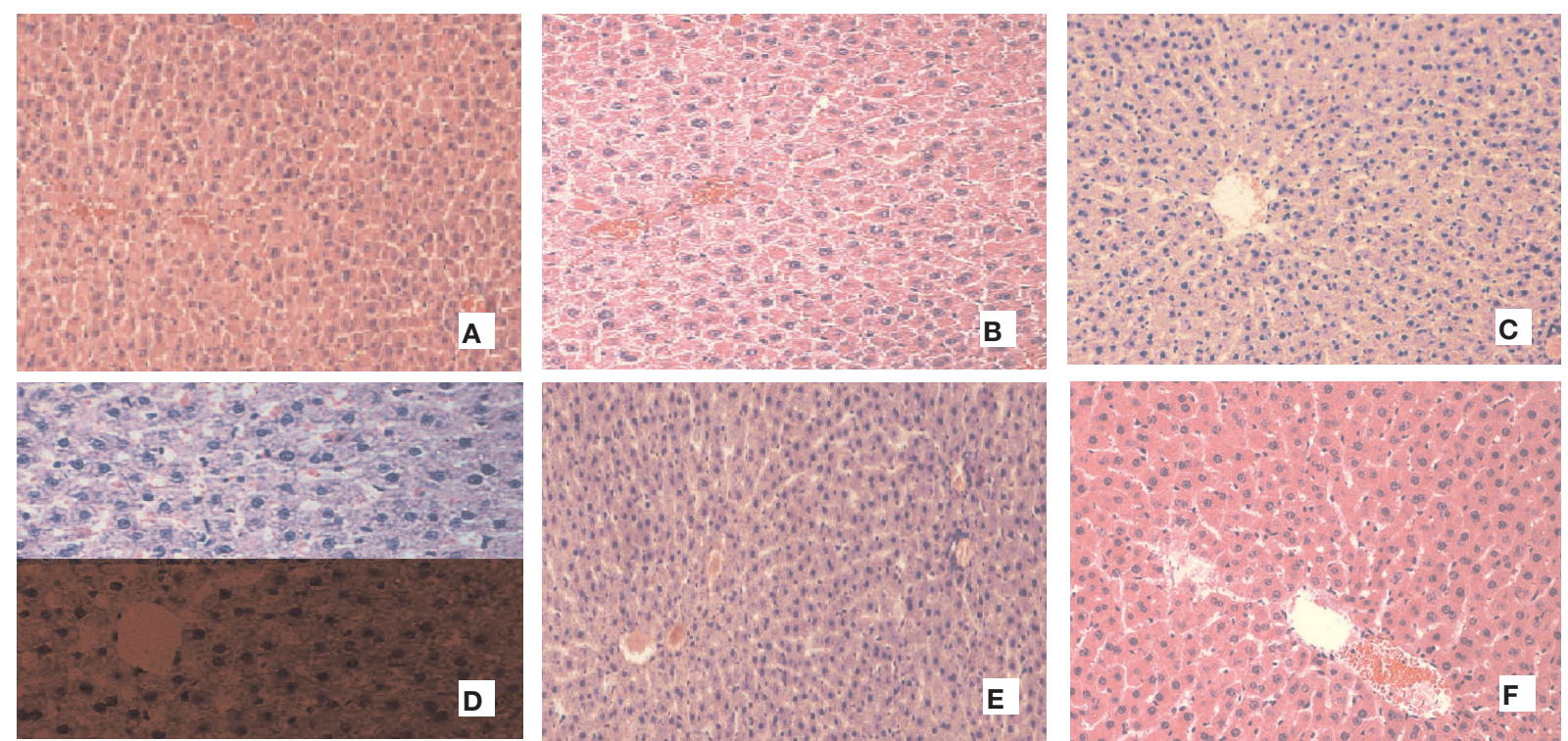

Figure 1. Light Microscopic Photomicrographs of Liver Tissues

Cisplatin group: Severe hydropic degeneration, necrose of hepatocytes, dilatation and vascular congestion in sinusoids, increased number of Kupffer cells and inflammatory cell infitration in portal triad region (A,B). GSE+Cisplatin, OOEO+Cisplatin, GSE+OOEO+Cisplatin groups: Moderate hydropic degeneration, activated Kupffer cells, no necrosis (C,D). Control, GSE, OOEO groups: Normal histological appearence of liver $(\mathrm{E}, \mathrm{F})$

as compared to the control group ( $\mathrm{p}<0.001)$, while the addition of OOEO decreased the MDA level to a lesser degree but this decrement was not remarkable ( $p>0.05)$. The MDA levels in the rats receiving cisplatin were significantly higher than in the other groups $(p<0.001)$. However, the addition of GSE and/or OOEO to the treatment significantly decreased the cisplatin-induced MDA increment ( $p$ $<0.001$; Figure 2a)

GSE and GSE+OOEO administration significantly increased SOD and GSH-Px activities as compared to the control group $(\mathrm{p}<0.001)$, while OOEO addition did not change antioxidant activity compared to the controls $(p>0.05)$. While cisplatin treatment significantly decreased liver SOD and GSH-Px activities ( $p<0.001$; Figure 2b and Figure 2c), GSE and/or OOEO treatment reversed these reductions in SOD and GSH-Px activities in the cisplatin group ( $<<0.001)$.

As expected, cisplatin caused significant increases in serum ALT and AST levels when compared to control levels (Figure 3a - 3b; $p<0.001$ ). Treatment with GSE and/or OOEO markedly reversed cisplatin-induced alterations in serum hepatocyte enzymes levels $(p<0.001)$.

\section{DISCUSSION}

Cisplatin, one of the most active cytotoxic agents against cancer, has several toxicities. Hepatotoxicity occurs during high dose treatment with cisplatin. ${ }^{27,28}$ El-Sayyad et al showed many histopathological abnormalities including inflammatory infiltration, hyperplasia, periportal fibrosis, marked disruption of hepatic cords and dilated blood sinusoids in the rats livers of receiving cisplatin. These changes were confirmed at ultrastructural level, including vesiculated rough endoplasmic reticulum and atrophied mitochondria.? The data in our study also revealed that even a single dose of cisplatin $(7 \mathrm{mg}$ $\mathrm{kg}^{-1}$ ) causes considerable damage in the liver, as assessed microscopically. The liver morphology was characterized by severe activation of Kupffer cells, degenerated hepatocytes and moderate enlargement of the sinusoids. The present study also showed also clinical evidence of cisplatin-induced liver injury, demonstrated by elevated activities of serum enzymes ALT and AST.

In various studies, it has been shown that cisplatin administration is associated with increased formation of free radicals and generates active oxygen species, such as superoxide anion and the hydroxyl ra- 


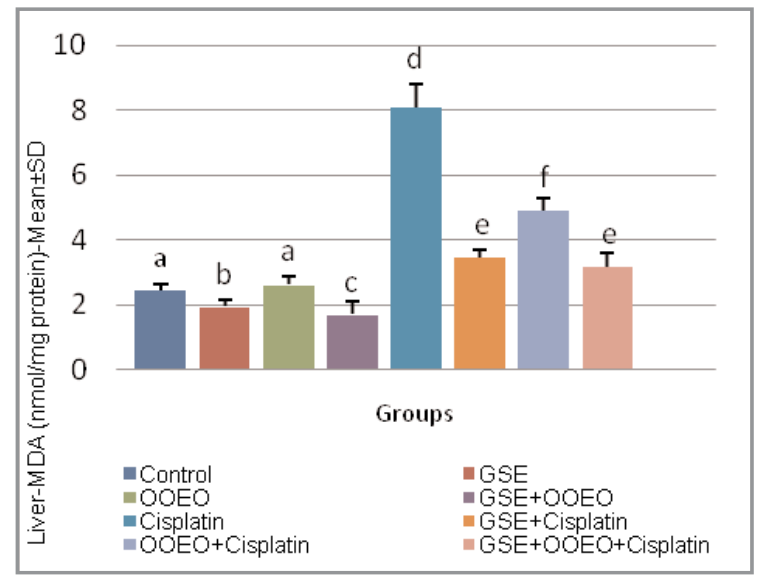

Figure 2a. MDA Levels of the Liver Tissues $(p<0.001)$

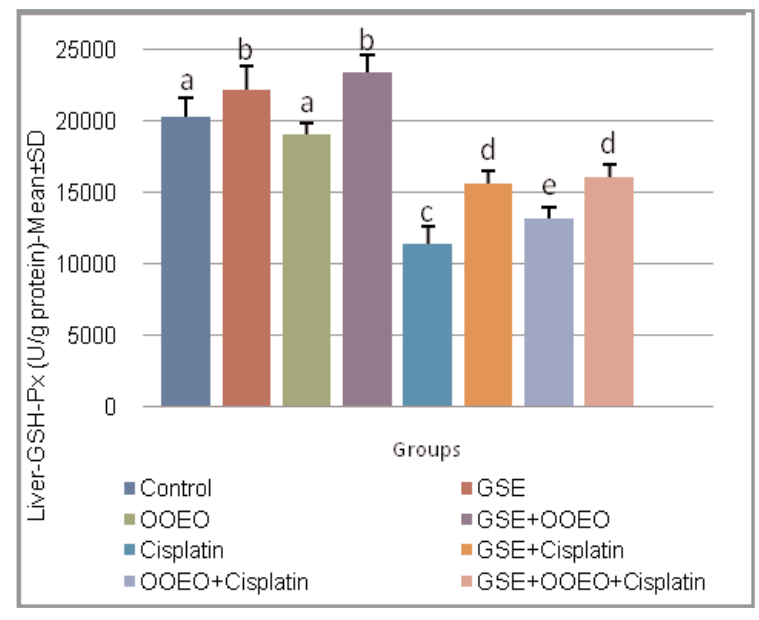

Figure 2c. GSH-Px Activities of the Liver Tissues $(p<0.001)$

dical. ${ }^{29,30}$ In the present study, an increment in MDA, a highly reactive compound and remarkable marker for oxidative stress and a decrement in GSH-Px and SOD activities, which are key antioxidants, were found in the liver of rats treated with cisplatin. After understanding the possible role of free radicals incispaltin-induced oxidative liver damage, several agents were added to the therapy as an adjuvant supplement and they attempted to protection and/or to prevent the side effects of chemotherapeutics. Recent studies have shown that different natural antioxidants such as vitamin $\mathrm{C}$, vitamin E, ellagic acid, nigella sativa, lycopen, caffeic acid phenethyl ester prevent cisplatin-induced toxicity. ${ }^{13,28,32-35}$ In this study, we investigated the effects of the natural antioxidants GSE and OOEO in cisplatin-treated rats by microscopic examination and biochemical assays.

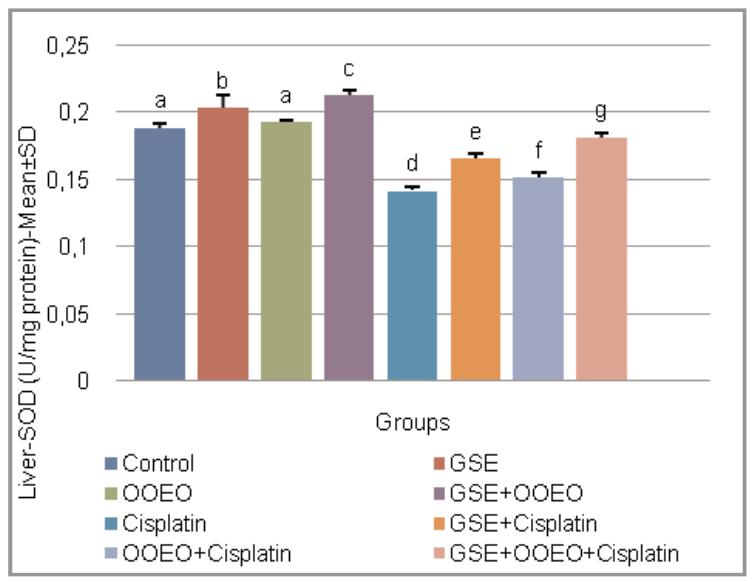

Figure 2b. SOD activities of the Liver Tissues $(p<0.001)$

Most grape products are rich sources of dietary chemical constituents that may have a potential for the prevention and treatment of human malignancies. ${ }^{36}$ These products have generated remarkable interest based on positive reports of their antioxidant properties and their ability to serve as free radical scavengers. ${ }^{15,37-38}$ Several studies have indicated that GSE inhibits the oxidation of LDL, inhibits the enzyme systems that are responsible for the production of free radicals is antimutagenic, and anticarcinogenic. ${ }^{39}$ Hence, GSE is widely consumed as a dietary supplement and could be useful in synergizing the efficacy of cancer chemotherapeutic agents in cancer treatment. The protective effect of GSE against chemotherapy-induced toxicity may be attributed to its potential to act as a hydrogen-donating free radical scavenger and singlet oxygen quencher and to their antioxidant activity. ${ }^{14}$ Similarly, in this study, the combined treatment of cisplatin and GSE resulted in a significant decrease in the MDA levels of liver tissue, a significant elevation in the antioxidant GSH-Px and SOD activities of tissues indicating the protection offered by GSE against cisplatin injury.

Carvacrol, the main constituent of OOEO, is an oxygenated monoterpene with multiple pharmacological actions including antioxidant, antitumoural, hepatoprotective activities..$^{17,19,40,41}$ It is also well known that essential oils which are rich in carvacrol possess strong antioxidant properties equivalent to those of ascorbic acid, butyl hydroxyl toluene and vitamin E. ${ }^{42}$ In the present study OOEO ameliorated the side effects of cisplatin by inhibiting lipid peroxidation. Contrary to our expectations, the 


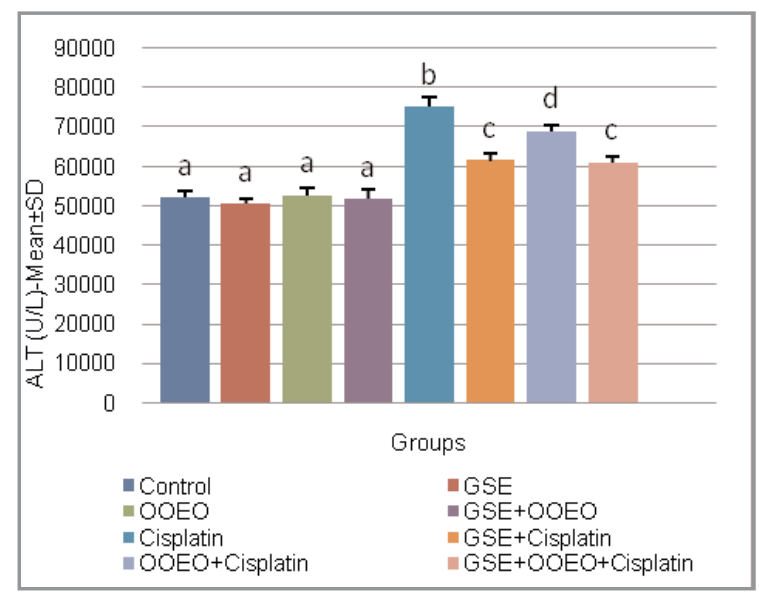

Figure 3a. Liver ALT Levels $(p<0.001)$

use of OOEO with GSE did not have a synergical antioxidant effect on cisplatin-induced oxidative stress. This additive effect may have a similiar antioxidant mechanism but further in-vivo and in-vitro experimental sets up are neeeded to explain the exact mechanism.

In conclusion, we showed that the experimental administration of cisplatin is accompanied by increased lipid peroxidation in rats. We therefore suggest that oxidative stress is a cause of cisplatin-induced pathophysiology. Simultaneously, we studied the co-administration of GSE and/or OOEO as an approach to ameliorate cisplatin-induced hepatotoxicity. These agents may protect against cisplatin-induced toxicity by overcoming the inactivation of antioxidant enzyme systems induced by cisplatin, and upregulating of SOD and GSH-Px activities in the liver. Our findings could provide a more promising strategy for the prevention of hepatotoxicity in cisplatin-based chemotherapy. However, additional studies with various doses, different time intervals, and a larger number of animals are necessary.

\section{REFERENCES}

1. Tsang RY, Al-Fayea T, Au HJ. Cisplatin overdose: Toxicities and management. Drug Saf 32: 1109-1122, 2009.

2. Greggi ALM, Darin JD, Bianchi M. Protective effects of vitamin $\mathrm{C}$ against cisplatin-induced nephrotoxicity and lipid peroxidation in adult rats. Pharmacol Res 41: 405-411, 2000.

3. Screnci D, McKeage MJ. Platinum neurotoxicity: Clinical profiles, experimental models and neuroprotective approaches. J Inorg Biochem 77: 105-110,1999.

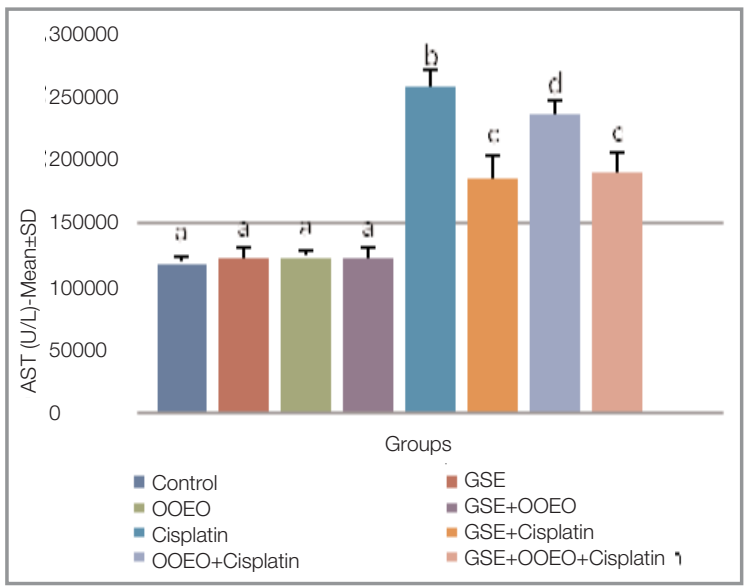

Figure 3b. Liver AST Levels $(p<0.001)$

4. Cersimo RJ. Hepatotoxicity associated with cisplatin chemotherapy. Ann Pharm 27: 438-441,1993.

5. Cavalli F, Tschopp L, Sonntag RW, Zimmermann A. A case of liver toxicity following cis-dichlorodiammineplatinum(II) treatment. Cancer Treat Rep 62: 21252126, 1978.

6. Pollera CF, Ameglio F, Nardi M, et al. Cisplatin induced hepatic toxicity. J Clin Oncol 5: 318-319, 1987

7. Sayyad HI, Ismail MF, Shalaby FM, et al. Histopathological effects of cisplatin, doxorubicin and 5-flurouracil (5-FU) on the liver of male albino rats Int $J$ Biol Sci 5: 466-473, 2009.

8. Fadillioglu E, Oztas E, Erdogan $\mathrm{H}$, et al. Protective effects of caffeic acid phenethyl ester on doxorubicin induced cardiotoxicity in rats. J App Toxicol 24: 47-52, 2004.

9. Fadillioglu E, Erdogan $\mathrm{H}$. Effects of erdosteine treatment against doxorubicin-induced toxicity through erythrocyte and plasma oxidant/antioxidant status in rats. Pharmacol Res 47: 317-322, 2003.

10. Blakley BW, Cohen JI, Doolittle ND, et al. Strategies for prevention of toxicity caused by platinum-based chemotherapy. Laryngoscope 112: 1997-2001, 2002.

11. Weijl NI, Elsendoorn TJ, Lentjes EG, et al. Supplementation with antioxidant micronutrients and chemotherapy-induced toxicity in cancer patients treated with cisplatin-based chemotherapy: a randomised, doubleblind, placebo-controlled study. Eur J Cancer 40: 1713-23, 2004.

12. Nazıroglu M, Karaoglu A, Aksoy OA. Selenium and high dose vitamin $\mathrm{E}$ administration protects cisplatininduced oxidative damage to renal, liver and lens tissues in rats. Toxicology 195: 221-230, 2004.

13. Custodio JB, Cardoso CM, Santos MS, et al. Cisplatin impairs rat liver mitochondrial functions by inducing changes on membrane ion permeability: Prevention by thiol group protecting agents. Toxicology 2: 18-24, 2009.

14. Bagchi D, Bagchi M, Stohs SJ, et al. Free radicals and grape seed proanthocyanidin extract: Importance in human health and disease prevention. Toxicology 148 : 187-197, 2000. 
15. Cetin A, Sagdic O. A Concise Review: Antioxidant Effects and Bioactive Constituents of Grape. Erciyes Med J 31: 369-375, 2009

16. Rapport L, Lockwood B. Proanthocyanidins and grape seed extract. Pharm J 266: 581-584, 2001.

17. Botsoglou NA, Taitzoglou A,Botsoglou IE, et al. Effect of Long-Term Dietary Administration of Oregano on the Alleviation of Carbon Tetrachloride-Induced Oxidative Stress in Rats. J Agric Food Chem 56: 62876293, 2008.

18. Damien HJ, Bachmayer D, Kosar M, Hiltunen R. Antioxidant Properties of Aqueous Extracts from Selected Lamiaceae Species Grown in Turkey. J Agric Food Chem 52: 766-770, 2004.

19. Karkabounas S, Kostoula L, Daskalou T, et al. Anticarcinogenic and antiplatelet effects of carvacrols. Exp Oncol 28: 121-125, 2006.

20. Cetin A, Kaynar L, Kocyigit I, et al. The effect of grape seed extract on radiation-induced oxidative stress in the rat liver. Turk J Gastroenterol 19: 92-98, 2008.

21. Yetim H, Sarioglu K, Ekici L, et al. Some characteristics of meats from the chickens fed with Lamiaceae spices: Proximate composition, lipid oxidation, color and sensory properties. Archive fur Lebensmittelhygiene 2010 (in press).

22. Ohkawa W, Ohishi N, Yagi K. Assay for lipid peroxides in animal tissues by thiobarbituric acid reaction. Anal Biochem 95: 351-358, 1979.

23. Lowry OH, Rosenbrough NJ, Farr Al, Randall RJ. Protein measurement with Folin phenol reagent. J Biol Chem 193: 265-275, 1951.

24. Sun Y, Oberley LW, Li Y. A simple method for clinical assay of superoxide dismutase. Clin Chem 34: 497 500, 1988.

25. Paglia DE, Valentine WN. Studies on the quantitative and qualitative characterization of erythrocyte glutathione peroxidase. J Lab Clin Med 70: 158-169, 1967.

26. Kart A, Cigremis $Y$, Karaman M, Ozen H. Caffeic acid phenethyl ester (CAPE) ameliorates cisplatin- induced hepatotoxicity in rabbit. Exp Toxicol Pathol 62: 45-52, 2010.

27. Zicca A, Cafaggi S, Mariggio MA, et al. Reduction of cisplatin hepatotoxicity by procainamide hydrochloride in rats. Eur J Pharmacol 442: 265-272, 2004.

28. Koc A, Duru M, Ciralik H, et al. Protective agent, erdosteine, against cisplatin-induced hepatic oxidant injury in rats. Mol Cell Biochem 278: 79-84, 2005.

29. Masuda H, Tanaka T, Takahama UT. Cisplatin generates superoxide anion by interaction with DNA in a cell-free system. Biochem Biophys Res Commun 203: 1175-1180, 1994.

30. Matsushima H, Yonemura K, Ohishi K, Hishida A. The role of oxygen free radicals in cisplatin-induced renal failure in rats. J Lab Clin Med 131: 518-526, 1988.

31. Weijl NI, Cleton FJ, Osanto S. Free radicals and antioxidants in chemotherapy-induced toxicity. Cancer Treat Rev 40: 209, 1997.
32. Antunes LMG, Darin JDC, Bianchi MLP. Protective effects of vitamin $C$ against cisplatin-induced nephrotoxicity and lipid peroxidation in adult rats. Pharmacol Res 41: 405-411, 2000.

33. Atessahin A, Karahan I, Türk G, et al. Protective role of lycopene on cisplatin-induced changes in sperm characteristics, testicular damage and oxidative stress in rats. Reprod Toxicol 21: 42-47, 2006.

34. Yüce A, Ateşşahin A, Ceribaşi AO, Aksakal M. Ellagic acid prevents cisplatin-induced oxidative stress in liver and heart tissue of rats. Basic Clin Pharmacol Toxicol 101: 345-349, 2007.

35. Rooney S, Ryan MF. Effects of alpha-hederin and thymoquinone, constituents of Nigella sativa, on human cancer cell lines. Anticancer Res 25: 2199-2204, 2005.

36. Wargovich M.J. Nutrition and cancer: The herbal revoIution. Curr Opin Clin Nutr Metab Care 2: 421-424, 1999.

37. Shi J, Yu J, Pohorly J, Kakuda Y. Polyphenolics in grape seeds: Biochemistry and functionality. J Med Food 6: 291-299. 2003

38. Cook NC, Sammam S. Flavonoids-chemistry, metabolism cardioprotective effects and dietary sources. J Nutr Biochem 7: 66-76, 1996.

39. Sharma GAK, Tyagi RP, Singh D, et al. Synergistic anti-cancer effects of grape seed extract and conventional cytotoxic agent doxorubicin against human breast carcinoma cells. Breast Cancer Res Treat 85:1-12, 2004.

40. Aristatile B, Al-Numair KS, Veeramani C, Pugalendi $K V$. Effect of carvacrol on hepatic marker enzymes and antioxidant status in D-galactosamine-induced hepatotoxicity in rats.Fundam Clin Pharmacol 23: 757-65, 2009.

41. Dundar E, Olgun EG, Isiksoy S, et al. The effects of intra-rectal and intra-peritoneal application of Origanum onites L. essential oil on 2,4,6-trinitrobenzenesulfonic acid-induced colitis in the rat. Exp Toxicol Pathol 59: 399-408, 2008.

42. Canbek M, Uyanoglu M, Bayramoglu G, et al. Effects of carvacrol on defects of ischemia-reperfusion in the rat liver. Phytomedicine 15: 447-52, 2008.

\section{Correspondence}

Dr. Aysun ÇETiN

Erciyes Üniversitesi Tıp Fakültesi

Biyokimya ve Klinik Biyokimya Anabilim Dalı

38039, Kayseri / TURKIYE

Tel: (+90.352) 4379348

e-mail: aysuncetin@yahoo.com 